\title{
Simultaneous measurement of nitrous acid, nitric acid, and nitrogen dioxide by means of a novel multipollutant diffusive sampler in libraries and archives
}

\author{
Francesca Vichi ${ }^{1}$, Ludmila Mašková2 ${ }^{*}$, Massimiliano Frattoni ${ }^{1}$, Andrea Imperialii and Jiří Smolík ${ }^{2}$
}

\begin{abstract}
Introduction: A novel multipollutant diffusive sampler for $\mathrm{HONO}_{1} \mathrm{HNO}_{3}$, and $\mathrm{NO}_{2}$ was used and tested at four different libraries/archives in different seasons. Two were located in Switzerland in Bern (Swiss National Library) and Geneve (Bibliotheque de Geneve), both with HVAC system equipped with filters for pollutants removal, and the other two in the Czech Republic in Teplice (Regional Library) and in Prague (National Archives), where in this case the former is naturally ventilated and whereas the latter is equipped with HVAC system with filtration.

Results: The ratios between indoor and outdoor concentrations of $\mathrm{NO}_{2}$ showed a greater penetration of pollutants indoors in the naturally ventilated library than in the filtrated archives. The indoor concentrations of $\mathrm{HNO}_{3}$ were very low probably due to the high deposition velocity of nitric acid on available surfaces. HONO concentration values were usually lower outdoors, which indicated that HONO was produced by reactions on indoor surfaces.

Conclusion: The results revealed that the reproducibility of the new multipollutant sampler measurements was reasonable (according to $\mathrm{EU}$ directives) for $\mathrm{NO}_{2}$ and $\mathrm{HNO}_{3}$ and that the newly developed multipollutant sampler can be used in archives and libraries, allowing to map the pollutants distribution indoors. Due to high efficiency of insulating systems normally employed and of filtration systems, the values recorded for the pollutants indoors are often lower than the detection limits.
\end{abstract}

Keywords: Diffusive sampling, Nitrous acid, Nitric acid, Nitrogen dioxide, Archive, Library, Indoor/outdoor ratio

\section{Background}

Nitrogen oxides penetrate from the outdoor to the indoor environment and can be transformed, through complex reaction pathways, into gaseous nitric $\left(\mathrm{HNO}_{3}\right)$ and nitrous acids (HONO) [1]. $\mathrm{HNO}_{3}$ is a very aggressive acid in contrast with HONO. The latter is not particularly active by itself, even if it is an important source of $\mathrm{OH}$ radicals, one of the most important air oxidants [2]. This air pollution cause oxidation and hydrolytic degradation of archive materials such as colour changes and reduction of degree of polymerisation of paper [3], decomposition

\footnotetext{
*Correspondence: maskova@icpf.cas.cz

${ }^{2}$ Institute of Chemical Process Fundamentals of the CAS, Rozvojová 135,

16502 Prague, Czech Republic

Full list of author information is available at the end of the article
}

of leather [4], corrosion of metals [5, 6], and damage of colorants [7-10].

Several works report measurements of nitrous and nitric acid in various indoor environments [11-13] and recent works highlight the importance of the former species as an emerging indoor pollutant [14], but studies in cultural heritage buildings are scarce $[15,16]$. A well established and known technique to collect these trace gases is represented by denuder sequence based systems [17-19], but this technique is time consuming and labour intensive. Diffusive sampling can overcome these problems since it represents an easy to use technique which exploits the spontaneous diffusion of species collected by specific absorbing media. Diffusive samplers have been used for air quality monitoring of single gases in cultural

\section{贷 Springer}

(c) 2016 Vichi et al. This article is distributed under the terms of the Creative Commons Attribution 4.0 International License (http://creativecommons.org/licenses/by/4.0/), which permits unrestricted use, distribution, and reproduction in any medium, provided you give appropriate credit to the original author(s) and the source, provide a link to the Creative Commons license, and indicate if changes were made. The Creative Commons Public Domain Dedication waiver (http://creativecommons.org/ publicdomain/zero/1.0/) applies to the data made available in this article, unless otherwise stated. 
heritage buildings [20-23]. Nevertheless, when conditions which promote the formation of $\mathrm{HONO}$ are present (high air moisture content and surface to volume ratio), especially indoors, monitoring of $\mathrm{NO}_{2}$ by diffusive sampling can result in overestimation since the interference of the former pollutant is not negligible [24]. Therefore to overcome this problem and to account correctly for the different species a novel multipollutant diffusive sampler was designed for simultaneous sampling of three different pollutants (nitric acid, nitrous acid, and nitrogen dioxide) collected at separate sampling stages [25]. After the laboratory development, these devices were used indoors in different dwellings, as reported in [25]. The campaigns described in the following were the first applications to places of interest for cultural heritage conservation, as libraries and archives, where a certain kind of control on environmental parameters is commonly present. The aim of this study was, indeed, to test the newly developed multipollutant sampler for evaluating the air quality inside different libraries with or without HVAC (heating and ventilating and air conditioning systems). The exposure period, after these first sampling trials, could then be adjusted according to the typical range of values found for the different pollutants in the indoors of interest. These preliminary trials were necessary to avoid the saturation of the absorbing pads and the collection of insufficient analyte to be determined after the exposure period. Furthermore the sampler was also exposed outdoors to compare the pollutants concentration values and calculate indoor/outdoor ratios.

\section{Methods}

\section{Sampling locations}

Over the last 4 years the multipollutant sampler was used in different periods inside archives and libraries. Two seasonal campaigns were carried out at four different libraries: two libraries in Switzerland (the Swiss National Library in Bern and the Bibliotheque de Geneve in Geneva) and two libraries in the Czech Republic (the National Archives in Prague and the Regional Library in Teplice). All the indoor activities in the libraries are very limited.

The library in Bern is a modern building composed of a ground floor and four underground levels (1UG-4UG), the building is equipped with a heating, ventilation, and air conditioning (HVAC) system providing air filtered through a particulate filter and active carbon. An additional Purafil purification system is installed at the floor 3UG where newspaper collection is stored. Five indoor sites were selected at the different levels and an outdoor site (OUT) was chosen as well. One site was placed at the ground floor (A26) and the other four monitoring sites were placed both at the entrance, just outside of the double door insulation (WA2UG and WA3UG), and inside the second and third underground level (2UG and 3UG) in the area insulated by the double door system. The overall volume of the building in Bern is of approximately $4500 \mathrm{~m}^{3}$.

The library in Geneva is a historical building with a HVAC system equipped with particulate filters. Three indoor sampling sites were selected: the first in a compactor (number 51 in the following), the second at "La Reserve" and the third in a corridor. An outdoor site was chosen also in Geneva where the diffusive samplers were placed in a balcony (OUT). The library in Geneva has a volume of approximately $200 \mathrm{~m}^{3}$.

The archive in Prague is located in a modern building. The indoor measurements were carried out in a depository of "Bohemian tables (BT)" and in a depository of "Archives of the Czech Kingdom (ACK)". The BT and ACK depositories have volumes of approximately 550 and $220 \mathrm{~m}^{3}$, respectively. Each depository is equipped with its own HVAC system with air recirculation. The HVAC systems in both depositories contain HEPA filters for removing airborne particles. In addition the AKC depository is equipped with filters for removing $\mathrm{NO}_{2}$ and $\mathrm{SO}_{2}$. The outdoor measurements were performed on a balcony of the building orientated toward a busy street (OUT).

The library in Teplice is equipped with double glassed windows and an electrical heating system, i.e., the only ventilation is through cracks and small openings in the building, windows and doors. The measurements were performed inside the library (IN) and just outside of the window oriented to the chateau park (OUT). The depository has a volume of approximately $450 \mathrm{~m}^{3}$.

One monitoring location in each indoor and outdoor site was selected, because other measurements confirmed that the indoor air is well mixed [26].

\section{Measurement campaigns}

Seasonal campaigns were conducted in Switzerland during the spring/summer period of 2011 (S1) and during winter and spring/summer 2012 (W, S2). Later other measurements were performed in the Czech Republic during three campaigns in spring/summer 2013 (S1, S2) and winter 2014 (W) (Table 1).

Three multipollutant samplers were exposed indoors and three outdoors for during each campaign at every location.

In parallel the exposure of single stage Analyst diffusive samplers (Marbaglass, Italy) provided measurements of $\mathrm{NO}_{2}$ and $\mathrm{NO}_{\mathrm{x}}$ during the campaigns in Switzerland. Other species $\left(\mathrm{HNO}_{3}, \mathrm{SO}_{2}, \mathrm{O}_{3}\right.$ and $\left.\mathrm{NH}_{3}\right)$ were also monitored by the Analyst samplers in the campaigns carried out in the Czech Republic, where in addition IVL 
Table 1 Monitoring scheme

\begin{tabular}{|c|c|c|c|c|c|c|}
\hline City & Location & Sites & Season & Campaign & Exposition period & $\begin{array}{l}\text { Other pollutants } \\
\text { measured }\end{array}$ \\
\hline \multirow[t]{3}{*}{ Bern } & \multirow{3}{*}{$\begin{array}{l}\text { Swiss National Library } \\
\text { (SNL) }\end{array}$} & \multirow{3}{*}{$\begin{array}{l}1 \text { level: site A26 } \\
2 \text { level: sites } 2 \text { UG; WA2UG } \\
3 \text { level: sites 3UG;WA3UG } \\
\text { Outdoor: Balcony }\end{array}$} & Spring/Summer & S1 & 10.06.2011-30.06.2011 & \multirow{3}{*}{$\mathrm{NO}_{2} ; \mathrm{NOx}$ (Analyst) } \\
\hline & & & Winter & W & $16.01 .2012-09.02 .2012$ & \\
\hline & & & Spring/Summer & $\mathrm{S} 2$ & $31.05 .2012-21.06 .2012$ & \\
\hline \multirow[t]{2}{*}{ Geneva } & \multirow{2}{*}{$\begin{array}{l}\text { Bibliotheque de Geneve } \\
\qquad(\mathrm{BdG})\end{array}$} & \multirow{2}{*}{$\begin{array}{l}\text { Site 1: Compactor } 51 \\
\text { Site 2: La Reserve } \\
\text { Site 3: Corridor } \\
\text { Outdoor: Balcony }\end{array}$} & Spring/Summer & S1 & 09.06.2011-23.06.2011 & \multirow[t]{2}{*}{$\mathrm{NO}_{2} ; \mathrm{NOx}$ (Analyst) } \\
\hline & & & Winter & W & 23.01.2012-14.02.2012 & \\
\hline \multirow[t]{3}{*}{ Prague } & \multirow[t]{3}{*}{ National archives } & \multirow{3}{*}{$\begin{array}{l}\text { Site 1: BT } \\
\text { Site 2: ACK } \\
\text { Outdoor: Window }\end{array}$} & Spring/Summer & S1 & $8.4 .2013-10.5 .1013$ & \multirow{3}{*}{$\begin{array}{l}\mathrm{HNO}_{3}, \mathrm{SO}_{2}, \mathrm{O}_{3} \text { and } \mathrm{NH}_{3} \\
\quad \text { (Analyst) } \\
\text { Acetic acid; formic acid (IVL) }\end{array}$} \\
\hline & & & & $\mathrm{S} 2$ & $10.5 .2013-11.6 .2013$ & \\
\hline & & & Winter & W & $6.1 .2014-6.2 .2014$ & \\
\hline \multirow[t]{3}{*}{ Teplice } & \multirow[t]{3}{*}{ Regional library } & \multirow{3}{*}{$\begin{array}{l}\text { Site } 1 \\
\text { Outdoor: Window }\end{array}$} & Spring/ & S1 & $9.4 .2013-9.5 .2013$ & \multirow{3}{*}{$\begin{array}{l}\mathrm{HNO}_{3}, \mathrm{SO}_{2}, \mathrm{O}_{3} \text { and } \mathrm{NH}_{3} \\
\quad \text { (Analyst) } \\
\text { Acetic acid; formic acid (IVL) }\end{array}$} \\
\hline & & & Summer & S2 & $9.5 .2013-10.6 .2013$ & \\
\hline & & & Winter & W & 7.1.2014-12.2.2014 & \\
\hline
\end{tabular}

diffusive samplers (Swedish Environmental Research Institute, Sweden) for monitoring formic and acetic acids were employed.

In both cases at least $10 \%$ of the total number of samplers was used for each campaign as field blanks. The blanks were prepared and handled along with other samplers except for the exposition to pollutants. Additionally, basic meteorological parameters including ambient temperature and relative humidity were measured at both locations in Czech Republic, both indoors and outdoors, by Tiny Tag data loggers (Gemini, UK).

\section{Multipollutant diffusive sampler}

The body of the multipollutant diffusive sampler is similar to the Analyst [27]. The internal design of the sampler, on the other hand, was changed to collect $\mathrm{HNO}_{3}$, on the first filter and $\mathrm{NO}_{2}$ and $\mathrm{HONO}$ in the successive absorbing pads.

A correct speciation of these compounds, intertwined through the hydrolysis mechanism according to the known pathway [28-30]:

$$
2 \mathrm{NO}_{2}+\mathrm{H}_{2} \mathrm{O} \rightarrow \mathrm{HONO}+\mathrm{HNO}_{3}
$$

could, indeed, only be achieved by the subsequent collection of the two species on successive reactive substrates.

Most frequently $\mathrm{NO}_{2}$, which is the predominant species in the atmosphere also due to the photolysis of $\mathrm{HONO}$ in the outdoor ambient air, can affect the measurements of the less abundant HONO. On the other hand, particularly indoors, when moisture and an elevated surface/ volume ratio is present, $\mathrm{NO}_{2}$ measurements can be overestimated as reported in [24]. Therefore there is a mutual interference on the measurement of these two species. In this case, since nitrite is the species collected and analytically determined to get to the atmospheric concentration of these pollutants, the selectivity in the sampling phase was achieved through the implementation of successive sampling stages. After the first filter used to collect $\mathrm{HNO}_{3}$, other two successive pads were used to collect these species, assuming that $\mathrm{HONO}$ and part of the $\mathrm{NO}_{2}$ would both react on the second, whereas only $\mathrm{NO}_{2}$, normally the most abundant, is collected on the successive filter. During the development of this diffusive sampler trials, aimed at quantifying the relative amounts of nitrite collected on the second and third filter at different $\mathrm{HONO} / \mathrm{NO}_{2}$ concentration ratios, were performed. The ratio of the amounts of analyte collected on the two filters at $\mathrm{RH}=0$ was determined and used in the calibration of the device.

Hence three polyethylene discs housing three active glass microfiber filters were placed along the same diffusive path of the former sampler. The first two filters perform the sequential collection of the two acidic species and the third filter is used to estimate the interference of $\mathrm{NO}_{2}$ on the HONO measurement and vice versa.

Before impregnation with the reactive solution, a washing procedure of the microfiber filters with sodium carbonate (5\%) and successive rinse (for three times) with deionized water was implemented to improve the quality of the blanks. The filters (Whatman GF/A) inside the first polyethylene disc were then coated by using a $0.1 \%$ $(\mathrm{w} / \mathrm{v})$ aqueous solution of sodium chloride then dried in an oven at $80^{\circ} \mathrm{C}$.

The following other two glass microfiber filters, used to collect HONO and to account for the interference of $\mathrm{NO}_{2}$, were impregnated by using a $1.8 \%(\mathrm{w} / \mathrm{v})$ aqueous solution of sodium carbonate containing $1.8 \%(\mathrm{w} / \mathrm{v})$ of glycerine, they were then dried in an oven at $80^{\circ} \mathrm{C}$. Filters are placed along the diffusive path in front of the alkaline carbon filter prepared according to the procedure already 
described [27] and positioned at the bottom of the device for the sole $\mathrm{NO}_{2}$ sampling. An enlarged scheme of the sampler is reported in Fig. 1.

\section{Chemical analysis procedure}

As for the other diffusive samplers, the multipollutant samplers at the end of collection time were sealed and successively analysed according to a procedure similar to the one reported elsewhere for $\mathrm{NO}_{2}$ [27]. In this case the filters were removed from the sampler, then they were extracted by adding a solution of sodium bicarbonate and carbonate, $0.3 \mathrm{mM} \mathrm{NaHCO}$ and $2.7 \mathrm{mM} \mathrm{Na}_{2} \mathrm{CO}_{3}$ in a plastic vial. The solution obtained was stirred with VIBROMIX 203 EVT (from Tehtnica, Železniki, Poland) and analysed through ion chromatography (IC) (Dionex ICS 1000 equipped with AS12A column. The concentrations of analytes such as nitrate and nitrite were determined referring to calibration curves constructed with water solutions prepared by opportune dilution of stock standards (Certipur from Merck, Milan, Italy) containing $1000 \mathrm{mg} / \mathrm{L}$ of each analyte.

\section{Results and discussion}

\section{Multipollutant diffusive sampler calibration}

Some information will be given concerning the calibration of the new device performed during the laboratory trials in the development phase. The prototypes of the new sampler were exposed to standard atmospheres containing the pollutants of interest in a smog chamber. The

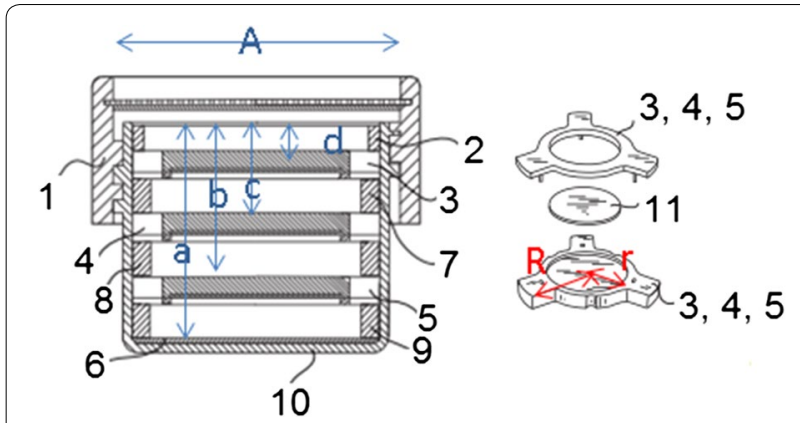

Fig. 1 Exploded scheme of the multipollutant sampler. 1 Plastic cap (before and after exposition) or air barrier (during exposition), 2 Ring, 3 Polyethylene holder of absorbing pad impregnated with $\mathrm{NaCl}\left(\mathrm{HNO}_{3}\right.$ sampling), 4 Polyethylene holder of absorbing pad impregnated with $\mathrm{Na}_{2} \mathrm{CO}_{3}$ ( $\mathrm{HONO}$ sampling), 5 Polyethylene holder of absorbing pad impregnated with $\mathrm{Na}_{2} \mathrm{CO}_{3}$ (interference of $\mathrm{HONO}$ and $\mathrm{NO}_{2}$ ), 6 Carbon Filter ( $\mathrm{NO}_{2}$ sampling), 7, 8, 9 Plastic spacer, 10 Body of the sampler, 11 Absorbing pad (containing $\mathrm{Na}_{2} \mathrm{CO}_{3}$ or $\mathrm{NaCl}$ ). Geometric features $A$ cross sectional area $\left(330 \mathrm{~mm}^{2}\right), R$ maximum length of the plastic support $(10 \mathrm{~mm}), r$ plastic support radius $(6.5 \mathrm{~mm}), a$ diffusive path to $\mathrm{NaCl}$ impregnated filter $(4.5 \mathrm{~mm}), b$ diffusive path to first $\mathrm{Na}_{2} \mathrm{CO}_{3}$ impregnated filter $(11.3 \mathrm{~mm}), \mathrm{c}$ diffusive path to second $\mathrm{Na}_{2} \mathrm{CO}_{3}$ impregnated filter $(17.1 \mathrm{~mm}), d$ diffusive path to impregnated carbon filter (24.0 mm) experimental setup was equipped with reference technique for the measurement of each species, the data were used to calibrate the new device. The calibration was achieved through comparison with denuder data: $\mathrm{NaCl}$ coated denuders were the reference for $\mathrm{HNO}_{3}$, whereas two $\mathrm{Na}_{2} \mathrm{CO}_{3}$ coated denuders [31] accounted for nitrous acid.

Successively the comparison between the two different techniques gave good results also in field trials (for $\mathrm{HNO}_{3} \mathrm{R}^{2}=0.97$; for HONO $\mathrm{R}^{2}=0.96$ ). The chemiluminescent analyser, used as a reference for $\mathrm{NO}_{2}$, was also in agreement with the newly developed diffusive sampler $\left(\mathrm{R}^{2}=0.97\right)$.

A paired $t$ test was performed to compare the data obtained by denuder technique and diffusive sampling [HONO: $t(10)=0.31 p=0.75 ; \mathrm{HNO}_{3}: t(10)=2.18$ $p=0.053]$, and by chemiluminescent analyzer and diffusive sampling $\left[\mathrm{NO}_{2}: t(10)=1.59 p=0.14\right]$. At a $p$ value of 0.05 , in all cases the results are consistent with the null hypothesis that there is no difference between techniques would be accepted, and certainly for HONO there is very good agreement; for $\mathrm{HNO}_{3}$ more measurements might in retrospect have been appropriate to form a more considered view.

A comparison with the Analyst sampler for $\mathrm{NO}_{2}$ was also performed. The Analyst differs from the multipollutant sampler for the geometry, since it is basically a cylinder open on one end, whereas the multipollutant has a rather complex structure (Fig. 1). The uptake rate $(U r)$, which is defined as:

$$
U r=\frac{D \cdot A}{L}
$$

where $D$ is the diffusion coefficient $\left(\mathrm{cm}^{2} / \mathrm{s}\right)$ of the gaseous species, $A$ is the cross-sectional area $\left(\mathrm{cm}^{2}\right)$ and $L$ the diffusive path $(\mathrm{cm})$, is quite different for the two samplers. The ratio between the uptake rate for $\mathrm{NO}_{2}$ for the Analyst and the multipollutant is 3 , being the $U r_{\text {Analyst }}$ about $12 \mathrm{~cm}^{3} / \mathrm{min}$ and $U r_{\text {Multipollutant }}$ about $4 \mathrm{~cm}^{3} / \mathrm{min}$ (measured at $\mathrm{RH}=0 \%$, in a dry atmosphere containing $\mathrm{NO}_{2}$ without $\mathrm{HONO}$ ). This feature of the newly developed diffusive sampler can explain the lower sensitivity to $\mathrm{NO}_{2}$ if compared to the Analyst, since in the same lapse of time the latter can collect a higher amount of analyte (nitrite), on the other hand the selectivity of multipollutant sampling is increased as already explained.

\section{In field use of Analyst and multipollutant sampler}

As a first approach, the agreement of the measurements of $\mathrm{NO}_{2}$ obtained by the Analyst sampler and by the multipollutant sampler was checked (Fig. 2). The correlation coefficient was quite good $\left(R^{2}=0.87\right)$, taking into account the whole set of measurements (both Swiss and Czech libraries and archives). 


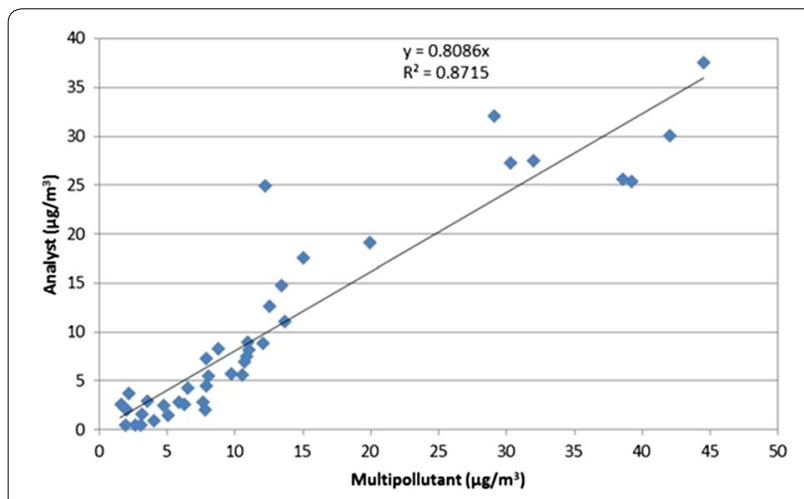

Fig. 2 Regression between the multipollutant and the analyst sampler results of $\mathrm{NO}_{2}$ measurements

The new multipollutant samplers and standard Analyst samplers were also compared by estimation of sensitivity given as limits of detection (LODs) and uncertainty given as relative standard deviations. The LODs were calculated as three times the standard deviation of blank samples [32]. The sensitivity of multipollutant and Analyst samplers was comparable for $\mathrm{HNO}_{3}$, but the Analyst samplers were more sensitive to low concentrations of $\mathrm{NO}_{2}$. The lowest detectable concentrations for the multipollutant samplers after one month exposure were found to be $1.4 \mu \mathrm{g} / \mathrm{m}^{3}$ for $\mathrm{NO}_{2}$, $0.2 \mu \mathrm{g} / \mathrm{m}^{3}$ for $\mathrm{HNO}_{3}$, and $0.5 \mu \mathrm{g} / \mathrm{m}^{3}$ for $\mathrm{HONO}$, and for the Analyst samplers $1.0 \mu \mathrm{g} / \mathrm{m}^{3}$ for $\mathrm{NO}_{2}$ and $1.0 \mu \mathrm{g} / \mathrm{m}^{3}$ for $\mathrm{HNO}_{3}$.

To assess the reproducibility [33] relative standard deviations were considered. Standard deviations were calculated for each set of replicates during the different campaigns. The standard deviations for multipollutant samples were found to be $4 \%$ for $\mathrm{NO}_{2}$ and $20 \%$ for $\mathrm{HNO}_{3}$ and for Analyst samplers $5 \%$ for $\mathrm{NO}_{2}$ and $26 \%$ for $\mathrm{HNO}_{3}$. These results were in agreement with the variations found by other studies [34, 35] and also fulfil the $\pm 25 \%$ uncertainty requirement of the European Directive for indicative monitoring with diffusion samplers [36]. Higher values of the standard deviations were found for $\mathrm{HONO}$ measured by the multipollutant samplers (approximately $68 \%$ ). HONO measurements reproducibility was likely affected by the really low values found indoors, which in many cases were below the detection limit, therefore the dataset was eventually composed by a narrow number of data.

$\mathrm{NO}_{2}$ and $\mathrm{HNO}_{3}$ concentrations values at the different locations in Swiss libraries, in particular at the SNL where abatement of the pollutants was achieved through the combination of different filters, were often lower than the detection limit.
Nitric acid concentrations were very low probably due to the very high deposition velocity on available surfaces $[1,37]$.

The extension of the exposure period was implemented to increase the amounts of analyte collected, optimizing the sampling length according to the sensitivity of the technique. Therefore the duration of the campaigns in Switzerland was of about 20 days, whereas the later campaigns in Czech Republic were extended to about a month.

\section{Indoor and outdoor concentrations}

Indoor pollutant concentrations are influenced by indoor sources and sinks and penetration from the outdoor environment. As it can be seen from a comparison of the different environments I/O (indoor/outdoor) ratios (Tables 2, 3, 4, 5), the efficiency of the filtration systems (turned off at Bern during the second and third campaign) in removing the pollutants does not seem to produce large differences in the environmental parameters measured. For HONO, when it was possible to perform the calculation, these ratios were always higher than 1 indicating that the formation of the pollutant happens indoors. In this case the filtration systems removing $\mathrm{NO}_{2}$ should avoid the formation of this pollutant, rather than removing it from infiltrating air.

The reaction (1) is negligible in the gas phase but occurs in the presence of surfaces, where produced $\mathrm{HNO}_{3}$ remains in the surface water film, whereas HONO forms an equilibrium shifted towards the gaseous phase [38].

According to (1) the equilibrium concentration of HONO should depend on $\mathrm{NO}_{2}$ concentration and relative humidity $\mathrm{RH}$.

The surface/volume ratio is also known [30] to affect both the formation of HONO and NO at different concentrations of $\mathrm{NO}_{2}$ and for different values of relative humidity.

It is in agreement with higher $\mathrm{NO}_{2}$ and $\mathrm{HONO}$ outdoor concentration in Prague than in Teplice. Indoor concentrations of HONO were found in the BT depository and the Teplice library, with similar indoor conditions: indoor $\mathrm{NO}_{2}$ concentrations (Tables 4, 5), RH (Table 6), and a surface/volume ratio $2.6 / \mathrm{m}$ and $2.9 / \mathrm{m}$ in Teplice and BT, respectively.

Moreover, HONO was not detected in the ACK depository, where $\mathrm{NO}_{2}$ concentrations were lower than the detection limit of both types of dosimeters. These results are in agreement with the production of HONO indoors from $\mathrm{NO}_{2}$ by reactions on exposed surfaces which include books and manuscripts, giving rise to acid deposition of $\mathrm{HNO}_{3}$. 
Table 2 The Swiss National Library in Bern campaigns results $\left(\mu \mathrm{g} / \mathrm{m}^{3}\right)$, bdl-below detection limit

\begin{tabular}{|c|c|c|c|c|c|c|c|c|c|}
\hline \multirow[t]{2}{*}{ Pollutant } & \multirow[t]{2}{*}{ Campaign } & \multicolumn{5}{|l|}{ Indoor } & \multirow{2}{*}{$\begin{array}{l}\text { Outdoor } \\
\text { OUT }\end{array}$} & \multirow[t]{2}{*}{ IN Average } & \multirow[t]{2}{*}{$1 / 0$} \\
\hline & & 3UG & WA3UG & $2 U G$ & WA2UG & A26-Coll & & & \\
\hline \multirow[t]{3}{*}{$\mathrm{NO}_{2}$} & S1 & bdl & bdl & bdl & bdl & $1.5 \pm 0.1$ & $6.4 \pm 0.3$ & 1.5 & 0.2 \\
\hline & W & bdl & $1.6 \pm 0.1$ & bdl & $1.9 \pm 0.1$ & $1.7 \pm 0.1$ & $31.1 \pm 1.2$ & 1.7 & 0.1 \\
\hline & S2 & $4.3 \pm 0.2$ & $2.8 \pm 0.1$ & $2.5 \pm 0.1$ & $3.0 \pm 0.1$ & $9.2 \pm 0.4$ & $12.0 \pm 0.5$ & 4.3 & 0.4 \\
\hline \multirow[t]{3}{*}{ HONO } & S1 & bdl & $2.5 \pm 1.7$ & $0.7 \pm 0.5$ & $2.7 \pm 1.8$ & $1.8 \pm 1.2$ & bdl & 1.9 & \\
\hline & W & $1.2 \pm 0.8$ & $1.7 \pm 1.2$ & bdl & $2.2 \pm 1.5$ & bdl & bdl & 1.7 & \\
\hline & S2 & $5.7 \pm 3.9$ & $3.3 \pm 2.3$ & $2.5 \pm 1.7$ & bdl & $11.0 \pm 7.5$ & $1.4 \pm 0.9$ & 5.6 & 4.2 \\
\hline \multirow[t]{3}{*}{$\mathrm{HNO}_{3}$} & S1 & $0.3 \pm 0.1$ & $0.2 \pm 0.0$ & bdl & bdl & bdl & $0.5 \pm 0.1$ & 0.2 & 0.4 \\
\hline & W & $0.4 \pm 0.1$ & $0.3 \pm 0.1$ & $0.3 \pm 0.1$ & bdl & bdl & bdl & 0.3 & \\
\hline & S2 & $0.2 \pm 0.0$ & $0.2 \pm 0.0$ & $0.2 \pm 0.0$ & $0.2 \pm 0.0$ & $0.3 \pm 0.1$ & $2.1 \pm 0.4$ & 0.2 & 0.1 \\
\hline
\end{tabular}

Table 3 The Bibliotheque de Geneve campaigns results $\left(\mu \mathrm{g} / \mathrm{m}^{3}\right)$, bdl_-below detection limit

\begin{tabular}{|c|c|c|c|c|c|c|c|}
\hline \multirow[t]{2}{*}{ Pollutant } & \multirow[t]{2}{*}{ Campaign } & \multicolumn{3}{|l|}{ Indoor } & \multirow{2}{*}{$\begin{array}{l}\text { Outdoor } \\
\text { OUT }\end{array}$} & \multirow[t]{2}{*}{ IN Average } & \multirow[t]{2}{*}{$1 / 0$} \\
\hline & & Depot 51 & La reserve & Corridor & & & \\
\hline \multirow[t]{2}{*}{$\mathrm{NO}_{2}$} & $S$ & $3.4 \pm 0.1$ & bdl & $4.5 \pm 0.2$ & $16.1 \pm 0.6$ & 3.9 & 0.2 \\
\hline & W & $10.8 \pm 0.4$ & $5.7 \pm 0.2$ & $11.4 \pm 0.5$ & $38.9 \pm 1.6$ & 9.3 & 0.2 \\
\hline \multirow[t]{2}{*}{ HONO } & $S$ & $4.0 \pm 2.7$ & bdl & $10.5 \pm 7.1$ & 0.0 & 7.2 & \\
\hline & W & $1.9 \pm 1.3$ & $1.4 \pm 0.9$ & $3.9 \pm 2.6$ & $2.0 \pm 1.4$ & 2.4 & 1.2 \\
\hline \multirow[t]{2}{*}{$\mathrm{HNO}_{3}$} & $S$ & $0.3 \pm 0.1$ & bdl & $0.5 \pm 0.1$ & $0.7 \pm 0.1$ & 0.4 & 0.6 \\
\hline & W & $0.3 \pm 0.1$ & $0.5 \pm 0.1$ & $0.5 \pm 0.1$ & $0.7 \pm 0.1$ & 0.4 & 0.6 \\
\hline
\end{tabular}

Table 4 The National Archives in Prague campaigns results $\left(\mu \mathrm{g} / \mathrm{m}^{3}\right)$, bdl-below detection limit

\begin{tabular}{llllll}
\hline Pollutant & Campaign & $\begin{array}{l}\text { Indoor } \\
\text { BT }\end{array}$ & $\begin{array}{l}\text { Outdoor } \\
\text { ACK }\end{array}$ & I/O OUT & \\
\hline $\mathrm{NO}_{2}$ & $\mathrm{~S} 1$ & $5.1 \pm 0.2$ & bdl & $44.5 \pm 1.8$ & 0.1 \\
& $\mathrm{~S} 2$ & $4.7 \pm 0.2$ & bdl & $31.0 \pm 1.2$ & 0.2 \\
& $\mathrm{~W}$ & $5.6 \pm 0.2$ & $\mathrm{bdl}$ & $42.0 \pm 1.7$ & 0.1 \\
$\mathrm{HONO}$ & $\mathrm{S} 1$ & $\mathrm{bdl}$ & $\mathrm{bdl}$ & bdl & \\
& $\mathrm{S} 2$ & $0.9 \pm 0.6$ & bdl & bdl & \\
& $\mathrm{W}$ & $2.2 \pm 1.5$ & bdl & $6.6 \pm 4.5$ & 0.3 \\
\hline
\end{tabular}

Table 5 The library of Regional Museum in Teplice campaigns results $\left(\mu \mathrm{g} / \mathrm{m}^{3}\right)$, bdl-below detection limit

\begin{tabular}{lllll}
\hline Pollutant & Campaign & $\begin{array}{l}\text { Indoor } \\
\text { IN }\end{array}$ & $\begin{array}{l}\text { Outdoor } \\
\text { OUT }\end{array}$ & I/O \\
\hline $\mathrm{NO}_{2}$ & $\mathrm{~S} 1$ & $3.1 \pm 0.1$ & $19.9 \pm 0.8$ & 0.2 \\
& $\mathrm{~S} 2$ & bdl & $12.2 \pm 0.5$ & 0.2 \\
& $\mathrm{~W}$ & $4.0 \pm 0.2$ & $29.1 \pm 1.2$ & 0.1 \\
$\mathrm{HONO}$ & $\mathrm{S} 1$ & $1.0 \pm 0.6$ & $0.9 \pm 0.6$ & 1.1 \\
& $\mathrm{~S} 2$ & bdl & bdl & \\
& $\mathrm{W}$ & $5.2 \pm 3.5$ & $1.9 \pm 1.3$ & 2.7 \\
\hline
\end{tabular}

The outdoor concentrations of the pollutants measured in the four cities reflect the seasonal trend, being higher everywhere during wintertime due to low atmospheric layers mixing. The cities of Geneva and Prague showed the highest values (about $40 \mu \mathrm{g} / \mathrm{m}^{3}$ ).

The concentration values of $\mathrm{NO}_{2}$ were always lower indoors than outdoors, which indicates that there were no indoor sources. Higher indoor values of $\mathrm{NO}_{2}$ were measured at WA3UG and WA2UG, the two rooms at the library in Bern where the insulation from double doors is not provided. In these two rooms the HONO levels were also higher than in the others. The A26 Collection, where a window is sometimes opened, the concentrations of the pollutants monitored were the highest at the library in Bern. The same can be observed for the corridor at the library in Geneva.

Relatively constant values of $\mathrm{NO}_{2}$ were observed at the first indoor site in Prague (BT) during all sampling periods. Concentrations measured inside the second indoor site (ACK) were always below detection limit. The difference in $\mathrm{NO}_{2}$ concentrations was probably caused by the efficiency of filters for $\mathrm{NO}_{2}$ in the HVAC system of the AKC depository compared to the BT depository equipped only with filters for particles. Indoor $\mathrm{NO}_{2}$ concentrations measured at Teplice were comparable to concentrations 
Table 6 Temperature and relative humidity

\begin{tabular}{|c|c|c|c|c|c|c|}
\hline & \multirow[t]{2}{*}{ Campaign } & \multicolumn{3}{|c|}{ Prague } & \multicolumn{2}{|c|}{ Teplice } \\
\hline & & BT & ACK & OUT & IN & OUT \\
\hline \multirow[t]{3}{*}{ Relative humidity (\%) } & I & 56 & 55 & 69 & 46 & 66 \\
\hline & $\|$ & 56 & 55 & 73 & 47 & 70 \\
\hline & III & 57 & 55 & 84 & 55 & 92 \\
\hline \multirow[t]{3}{*}{ Temperature $\left({ }^{\circ} \mathrm{C}\right)$} & । & 14.3 & 14.9 & 14.5 & 20.2 & 15.0 \\
\hline & $\|$ & 15.0 & 15.0 & 14.8 & 22.5 & 16.0 \\
\hline & III & 12.9 & 14.8 & 3.8 & 12.0 & 2.2 \\
\hline
\end{tabular}

in BT though outdoor concentrations were lower. This was probably due to the higher natural ventilation in this library as compared to the isolated archives.

\section{Conclusions}

The results revealed that the reproducibility of the new multipollutant sampler measurements was reasonable (according to EU directives) for $\mathrm{NO}_{2}$ and $\mathrm{HNO}_{3}$. The measured data were comparable with the standard Analyst sampler results, but differ for lower $\mathrm{NO}_{2}$ concentrations, probably due to differences in sampling and analytical procedure.

The results showed that the newly developed multipollutant sampler can be used in archives and libraries, allowing to map the pollutants distribution indoors. Due to high efficiency of insulating systems normally employed (such as double doors etc.) and filtration systems, the values recorded for the pollutants indoors are often lower than the detection limits. Hence HONO and $\mathrm{HNO}_{3}$ measurements were carried out in very "clean" environments, and the dataset eventually available was likely not wide enough to truly assess the reproducibility of the measurements, especially for the former pollutant.

\section{Authors' contributions}

FV design of the monitoring project and discussion of the results. LM samplings organization and revision of the manuscript. MF technical support in the laboratory. Al analytical activity. JS revision of the manuscript. All authors read and approved the final manuscript.

\section{Author details}

${ }^{1}$ Institute of Atmospheric Pollution Research, Italian National Research Council, Via Salaria Km. 29,300, Monterotondo Stazione, 00016 Rome, Italy. ${ }^{2}$ Institute of Chemical Process Fundamentals of the CAS, Rozvojová 135, 165 02 Prague, Czech Republic.

\section{Acknowledgements \\ The measurements in Switzerland were made possible by the kind help of Carmen Effner and Giovanna Di Pietro della Hochschule der Künste (Bern). The monitoring project organization in Czech Republic was supported by CAS/CNR Bilateral Agreement Exchange Programme, which funded the exchange of visits between the Italian and the Czech research groups.}

\section{Competing interests}

The authors declare that they have no competing interests.
Received: 22 May 2015 Accepted: 11 February 2016

Published online: 22 February 2016

\section{References}

1. Spicer CW, Kenny DV, Ward GF, Billick IH. Transformations, lifetimes, and sources of $\mathrm{NO}_{2}, \mathrm{HONO}$, and $\mathrm{HNO}_{3}$ in indoor environments. J Air Waste Manage. 1993;43:1479-85.

2. Jenkin ME, Cox RA, Williams DJ. Laboratory studies of the kinetics of formation of nitrous acid from the thermal reaction of the nitrogen dioxide and water vapour. Atmos Environ. 1988;22(3):487-98.

3. Menart E, De Bruin G, Strlič M. Dose-response functions for historic paper. Polymer Deg Stability. 2011;96(12):2029-39.

4. Larsen R. Experiments and observations in the study of environmental impact on historical vegetable tanned leathers. Thermochim Acta. 2000;365:85-99.

5. Samie F, Tidblad J, Kucera V, Leygraf C. Atmospheric corrosion effects of $\mathrm{HNO}_{3}$ - Influence of concentration and air velocity on laboratoryexposed copper. Atmos Environ. 2006;40(20):3631-9.

6. Samie F, Tidblad J, Kucera V, Leygraf C. Atmospheric corrosion effects of $\mathrm{HNO}_{3}$ - Comparison of laboratory-exposed copper, zinc and carbon steel. Atmos Environ. 2007;41(23):4888-96.

7. Grosjean D, Salmon LG, Cass GR. Fading of organic artists' colorants by atmospheric nitric acid: reaction products and mechanisms. Environ Sci Technol. 1992;26:952-9.

8. Grosjean D, Grosjean E, Williams EL. Fading of Artists' Colorants by a Mixture of Photochemical Oxidants. Atmos Environ. 1993;27A(5):765-72.

9. Katsanos NA, De Santis F, Cordoba A, Roubani-Kalantzopoulou F, Pasella D. Corrosive effects from the deposition of gaseous pollutants on surfaces of cultural and artistic value inside museums. J Hazard Mater. 1999;64:21-36.

10. Whitmore PM, Cass GR. The Fading of Artists' Colorants by Exposure to Atmospheric Nitrogen Dioxide. Stud Conser. 1989;34(2):85-97.

11. Brauer M, Ryan PB, Suh HH, Koutrakis P, Spengler JP. Measurements of nitrous acid inside two research houses. Environ Sci Technol. 1990;24:1521-7.

12. Park SS, Hong JH, Lee JH, Kim YJ, Cho SY, Seung JK. Investigation of nitrous acid concentration in an indoor environment using an in situ monitoring system. Atmos Environ. 2008;42:6586-96.

13. Khoder MI. Nitrous acid concentrations in homes and offices in residential areas in Greater Cairo. J Environ Monit. 2002;4:573-8.

14. Gligorovski S. Nitrous acid (HONO) An emerging indoor pollutant. J Photochem Photobiol, A Chemistry. 2016;314:1-5.

15. Chianese E, Riccio A, Duro I, Trifuoggi M, lovino P, Capasso S, Barone G. Measurements for indoor air quality assessment at the Capodimonte Museum in Naples (Italy). Int J Environ Res. 2012;6(2):509-18.

16. De Santis F, Di Palo V, Allegrini I. Determination of some atmospheric pollutants inside a museum: relationship with the concentration outside. Sci Total Environ. 1992;127(3):211-23.

17. Benner $C L$, Eatough NL, Lewis EA, Eatough DJ. Diffusion coefficients for ambient nitric and nitrous acids from Denuder experiments in the 1985 nitrogen species methods comparison study. Atmos Environ. 1988;22(8):1669-72 
18. Genfa Z, Slanina S, Boring CB, Jongejan PAC, Dasgupta PK. Continuous wet denuder measurements of atmospheric nitric and nitrous acids during the 1999 Atlanta Supersite. Atmos Environ. 2003;37(9-10):1351-64.

19. Febo A, Perrino C, Cortiello M. A denuder technique for the measurement of nitrous acid in urban atmospheres. Atmos Environ. 1993;27(11):1721-8.

20. López-Aparicio S, Smolík J, Mašková L, Součková M, Grøntoft T, Ondráčková L, Stankiewicz J. Relationship of indoor and outdoor air pollutants in a naturally ventilated historical building envelope. Build Environ. 2011;46:1460-8.

21. Godoi RHM, Carneiro BHB, Paralovo SL, Campos VP, Tavares TM, Evangelista H, Van Grieken R, Godoi AFL. Indoor air quality of a museum in a subtropical climate: the Oscar Niemeyer museum in Curitiba, Brazil. Sci Total Environ. 2013;452:314-20.

22. Krupinska B, Van Grieken R, De Wael K. Air quality monitoring in a museum for preventive conservation: results of a three-year study in the Plantin-Moretus Museum in Antwerp, Belgium. Microchem J. 2013;110:350-60

23. Grøntoft T, Odlyha M, Mottner P, Dahlin E, López-Aparicio S, Jakiela S, Scharff M, Andrade G, Obarzanowski M, Ryhl-Svendsen M, Thickett D, Hackney S, Wadum J. Pollution monitoring by dosimetry and passive diffusion sampling for evaluation of environmental conditions for paintings in microclimate frames. J Cult Heritage. 2010;11(4):411-9.

24. Spicer $C W$, Billick $I H$, Yanagisawa $Y$. Nitrous acid interference with passive $\mathrm{NO}_{2}$ measurement methods and the impact on indoor $\mathrm{NO}_{2}$ data. Indoor Air. 2001;11:156-61.

25. Vichi F. Development of a diffusive sampler for the simultaneous measurement of nitrogen dioxide, nitrous acid and nitric acid by means of a novel, multipollutant diffusive sampler. Ph.D. Dissertation 2013. University of Rome La Sapienza, 89 pp, http://padis.uniroma1.it/handle/10805/29/ browse?type $=$ author\&order $=$ ASC $\&$ rpp $=20 \&$ value $=$ VICHI\%2C+FRANCE SCA.

26. Mašková L. Characterization of Aerosol Particles in the Indoor Environment of Different Types of Libraries and Archives. Ph.D. Dissertation 2015. Charles University in Prague, 124 pp, https://is.cuni.cz/webapps/zzp/ detail/83446/.

27. De Santis F, Dogeroglu T, Fino A, Menichelli S, Vazzana C, Allegrini I. Laboratory development and field evaluation of a new diffusive sampler to collect nitrogen oxides in the ambient air. Anal Bioanal Chem. 2002;373:901-7.

28. Svensson R, Ljungström $E$, Lindqvist $O$. Kinetics of the reaction between nitrogen dioxide and water vapour. Atmos Environ. 1987;21:1529-39.

29. Kleffmann J, Becker $\mathrm{KH}$, Wiesen P. Heterogeneous $\mathrm{NO}_{2}$ conversion processes on acid surfaces: possible atmospheric implications. Atmos Environ. 1998;32:2721-9.

30. Finlayson-Pitts BJ, Wingen LM, Sumner AL, Syomin D, Ramazan KA. The heterogeneous hydrolysis of $\mathrm{NO}_{2}$ in laboratory systems and in outdoor and indoor atmospheres: an integrated mechanism. Phys Chem Chem Phys. 2003;5:223-42.

31. Perrino C, DeSantis F, Febo A. Criteria for the choice of a denuder sampling technique devoted to the measurement of atmospheric nitrous and nitric acids. Atmos Environ. 1990;24:617-26.

32. MacDougall D, Crummett WBB, et al. Guidelines for data acquisition and data quality evaluation in environmental chemistry. Anal Chem. 1980:52:2242-9.

33. ISO 5725-1:1994. Accuracy (trueness and precision) of measurement methods and results_-Part 1: General principles and definitions. Ed. 1.

34. Stevenson K, Bush T, Mooney D. Five years of nitrogen dioxide measurement with diffusion tube samplers at over 1000 sites in the UK. Atmos Environ. 2001;35:281-7.

35. Gerboles M, Buzica D, Amantini L, Lagler F. Laboratory and field comparison of measurements obtained using the available diffusive samplers for ozone and nitrogen dioxide in ambient air. J Environ Monit. 2006;8:112-9.

36. EU. Council directive 1999/30/EC relating to limit values for sulphur dioxide, nitrogen dioxide and oxides of nitrogen, particulate matter and lead in ambient air. Off J Eur Communities Legis. 1999; L163/41.

37. Walcek $\mathrm{CJ}$, Brost RA, Chang JS. $\mathrm{SO}_{2}$, sulfate and $\mathrm{HNO}_{3}$ deposition velocities computed using regional landuse and meteorological data. Atmos Environ. 1986;20(5):949-64.

38. Febo A, Perrino C. Prediction and experimental evidence for high air concentration of nitrous acid in indoor environments. Atmos Environ. 1991;25A:1055-61.

\section{Submit your manuscript to a SpringerOpen ${ }^{\odot}$ journal and benefit from:}

- Convenient online submission

- Rigorous peer review

- Immediate publication on acceptance

- Open access: articles freely available online

- High visibility within the field

- Retaining the copyright to your article

Submit your next manuscript at $>$ springeropen.com 